\title{
Cosmetology Field and It's Significance for Education and Industry Sector
}

\author{
Tee Tze Kiong, Farah Najwa Ahmad Puad, Elia Md Zain, Yee Mei Heong, Nurulwahida Azid
}

\begin{abstract}
The purpose of this paper was to identify the trends in cosmetology field. This paper also provides the definition of cosmetology, cosmetics, and other pertinent terms. Gathered articles were identified using electronic databases such as Google Scholar, Science Direct and Eric from year 2010 to 2019. These reviews found that training and earning professional licensing are crucial for cosmetologist to sustain in the beauty industry. Furthermore, these reviews bring researcher to relate that there is a lack of study in cosmetology education and teaching. Whereas, this cosmetology field is vast and growing nowadays. So that, the results of this study suggest that future study needs to be conducted to examine the educational intervention on effective learning and teaching strategies in cosmetology fields. This will provide more information required for the development of cosmetology curriculum to support students' academic interests, knowledge and skills in cosmetology.
\end{abstract}

Keywords: Cosmetology education, narrative analysis, careers, vocational education

\section{INTRODUCTION}

Education is a sequence of process to develop the ability, attitude and behavior of individuals in a holistic and integrated way [1]. Education also is a crucial and beneficial resource to sustain the economic growth and productivity of a nation [2]. There are conventional and technical and vocational education (TVET) regard to [1]. Due to the rapid improvement of technology and elevation of living standards, cosmetology education (CE) become one of the demanding branches of TVET that is intentionally related to aesthetics, beauty care and treatment [3] and it involves a broad range of studies from aesthetics to health and from cosmetics to care

Revised Manuscript Received on December 30, 2019.

* Correspondence Author

Tee Tze Kiong, Senior Lecturer, Faculty of Technical and Vocational Education, Universiti Tun Hussein Onn Malaysia, 86400 Parit Raja, Batu Pahat, Johor, Malaysia. E-mail: tktee@uthm.edu.my

Farah Najwa Ahmad Puad*, Faculty of Technical and Vocational Education, Universiti Tun Hussein Onn Malaysia, 86400 Parit Raja, Batu Pahat, Johor, Malaysia. E-mail: farahnajwa@ftv.upsi.edu.my

Elia Md Zain, Faculty of Technical and Vocational Education, Universiti Tun Hussein Onn Malaysia, 86400 Parit Raja, Batu Pahat, Johor, Malaysia. E-mail: tktee@uthm.edu.my

Yee Mei Heong, Faculty of Technical and Vocational Education, Universiti Tun Hussein Onn Malaysia, 86400 Parit Raja, Batu Pahat, Johor, Malaysia. E-mail: mhyee@uthm.edu.my

Nurulwahida Azid @ Aziz, Education and Modern Languages, UUM College of Arts and Sciences, Universiti Utara Malaysia. E-mail: nurulwahida@uum.edu.my

(C) The Authors. Published by Blue Eyes Intelligence Engineering and Sciences Publication (BEIESP). This is an open access article under the CC BY-NC-ND license (http://creativecommons.org/licenses/by-nc-nd/4.0/)
[1]. [4], state that cosmetology fields have existed on the world since the ancient times of the early 3000's (BC). During that time, The Egyptians are embracing the culture of embellishments as a luxury style / trend [5]. Finally, the embellishments culture turns into a personal beautification habit, preparation of the deceased for burial or preparation for religious ceremonies.

The Egyptians produced their cosmetic products from minerals, insects and berries. Subsequently, history also shows that the cosmetology field was evolved by The Chinese during the Shang Dynasty (circa 1600 BC), followed by The Greeks (circa 500 BC) and The Romans. Next, it was further developed by The Middle Ages (AD 476 to 1450), The Renaissance, The Victorian Age (1837 to 1901), The Twentieth Century (1901-2000) and to this day. Numerous changes have been occurred over the time in terms of cosmetic products, the use of technology and career path that individuals can pursue in this field. The career that is merged into this field are cosmetologists, hairdressers, trichologists, aestheticians, nail technicians, cosmeatrics [6] and others.

So that, to have a quality career in beauty sector, CE is very essential to the beauty industry as it is one of the industries that contribute to a country's economic growth [1]. Nowadays, no longer women but even men are also taken substantially serious against the aesthetics and beauty care [7]; [8]. According to [1] and [4], CE not only exposes knowledge and skills in beauty care and treatment but additionally educates people on the attitudes and behavior that need to be applied in the career to be pursued. CE is taught to the students and who is interested in beauty sectors through formal and informal education way [1]. Formal education in CE regard to [1] is the type of education which is regulated by the laws and aims to provide individuals with general and vocational knowledge while informal education is education that can occur outside a structured curriculum. Formal CE in Malaysia is taught in several Public (IPTA) and Private Institutions of Higher Learning (IPTS); Community Colleges (JPPKK); Vocational Colleges (KV); Upper Secondary Vocational Program (PVMA) under the National Secondary Schools (SMK) and Giatmara. Whilst, the informal CE is taught in private workshops whether for free or paid. Technical knowledge and skills or hard skills that are emphasized in CE includes cares and treatments for the face; body; hand, foot and nail (manicure \& pedicure); hair; epilation and make up. Other than that, CE also emphasized on life skills and soft skills [4]. Communication skills [9]; [10]; professional ethics and moral [11]; [12]; [13] and entrepreneurial skills [14] are the amongst of the soft skills

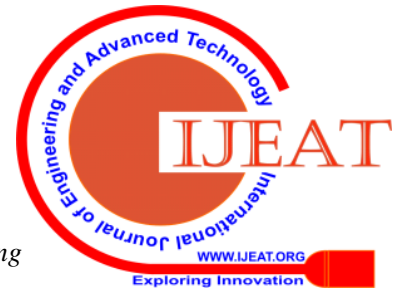


that are essential in $\mathrm{CE}$ and beauty career. It is crucial to nurture soft skills amongst the CE students due to this sector are related to service providers and is closely to customers.

[14] emphasize that cosmetology students who are poor in hard skills and soft skills will be challenging in sustaining their profession. In this article, researchers aim to outline past studies related to cosmetology field.

\section{DEFINITIONS AND CAREER PATH RELATED TO COSMETOLOGY FIELD}

There are various terms that related to cosmetology field that we need to know. The important term is the definitions of cosmetology itself which can be defined as "the body beautiful" and practices that related to this study [6]. Next is dermatology which is it specialty field focus to all matters of the skin in health and disease. [6]. Another term that related is the cosmetic term. It refers to the quality of the beauty or the product used to expose the external individuals' beauty. There are two types of cosmetic products which are skincare products and make-up products. The skincare products are normally used to care the skin health, to attain soft, supple pores and skin and so to prevent negative effects due to external causes while the make-up products used to minimize the facial defects, enhance beauty and concealed the blemishes [6].

Individuals who are educated in cosmetology can pursue a career as a hairdresser, cosmetologist, beautician, body care and massage specialist, esthetician, nail technician, cosmeatric, make-up artist, beauty therapist, beauty consultant and dermatologist [9]; [5]; [1]; [3]. [6] states that cosmetologist is synonym to beautician. However, there is a contradiction among experts about the term cosmetologist where some experts classify cosmetologists as scientists who produce cosmetic products such as chemists, pharmacists, pharmacologists and cosmetic chemists [6]. But, [9] and [5] revealed that cosmetologist as individuals who received training and also hold professional license in the art of cutting and styling hair, manicuring nails, performing skin treatments and applying make-up.

Other than cosmetologist, dermatologist and trichologist are also the careers that related to cosmetology. Different with other cosmetology career whereby they work in salons or spas, dermatologist and trichologist employed in hospitals and clinics. Dermatologist must be knowledgeable on the structure and health of the skin, and they also need to know how to properly cleanse and care for the skin. While trichologist specialize in the treatment of diseases and disorders of hair and scalp. Other than that, they are also played a big role to cooperate and advice beauticians, estheticians, hairdressers and make-up artist regarding the skin health, hair and scalp [3].

Next career is make-up artist and beauticians where they have to master in make-up skills, face anatomy, biochemistry, skin physiology, pathology and pathophysiology [3]; [6]. They have to master in this sub field due to the different types of customers' skin condition [6]. Before they start to make-up their customers, they have to examine their customers' contra indications to avoid the negative effects on the customers' skin. Nowadays, the online shop was considered the best for preference and reliability for customers to buy skincare products [15] but they still attached greater weight to its quality, price and ingredients [16]. Other than that is cosmiatric where this term of career is given by [6]. The cosmiatric term is derived from the word Greek which is cosmos and iatros. Cosmos means beautiful while iatros means physicians. So, [6] declared that cosmiatric as individual who gives beauty treatments to the clients.

\section{COSMETOLOGY FIELD AMONG THE WORLD}

The cosmetology education is being taught to the students and who is interested all over the world. In Turkey, they declared cosmetology education as esthetician education and it is performed as formal and informal training [1]. Formal cosmetology education in Turkey aims to provide individuals with general and vocational knowledge and institutions which offering formal education consist of professional secondary and higher education cosmetology training schools. Whilst informal cosmetology education on the other hand is offered in the form of short-term vocational courses conducted by both public and private institutions.

While in Arizona, to become a cosmetologist, students can start their cosmetology training in vocational high school before they get their high school diploma [5]. After graduate in high school, they have to complete some training whether at a college or university and earn a cosmetology license before they are legitimate as cosmetologist [17]. [5] states that to earn a licensed for cosmetologist, students need to complete hours of practice and training to gain experience and it is differences among the countries. In Arizona, students need to complete 1600 hours of training, New York for 1000 hours of training, United States for 2000 hours of training, Idaho for 2000 hours of training or 4000 hours of apprenticeships just to earn for cosmetologist license.

In Malaysia, there are four departments under Ministry of Education Malaysia (Kementerian Pendidikan Malaysia-KPM) which offered courses related to cosmetology. The departments are Higher Education Department (Jabatan Pendidikan Tinggi-JPT), Department of Polytechnic Education and Community College (Jabatan Pendidikan Politeknik dan Kolej Komuniti-JPPKK), Technical and Vocational Education Division (Bahagian Pendidikan Latihan Teknik dan Vokasional-BPLTV) and Public Skills Training Institutes (Institut Latihan Kemahiran Awam-ILKA). However, the name of the program or course used are different by each institution. Some institutions under the JPPKK, BPLTV and ILKA offer Malaysian Skills Certificate (SKM) level 1 to 3; Malaysian Skills Diploma (DKM) Level 4; Malaysian Advanced Skills Diploma (DKLM) Level 5; Malaysian Vocational Diploma (DVM) or Vocational Training Officer (VTO) to students who are qualified. So that, they can build up their career in the industry, self-employed in their own beauty organization or accredited centers to trained others. But, it is different to IPTA which offered this vocational education under education programmed whereby it is designed to provide graduates with the knowledge, skills and qualifications to teach cosmetology education in high school or vocational college. 
Despite that, Faculty of Technical and Vocational, Universiti Pendidikan Sultan Idris (UPSI) gave advantage for students to acquire SKM certificate in cosmetology level 2 as value added in preparation for them to teach. [18] suggest that experienced and quality teachers are significant parameter for students to get much interests in such field. Therefore, for being a quality cosmetology teacher, cosmetology students should not only depend on the certificate they earned, but they have to master in cosmetology knowledge, hard skills, soft skills and life skills [5]; [4].

\section{PROPOSED METHODOLOGY}

The matrix literature review of results analyses is retrieved from hand searches and computerized databases like Google Scholar, ERIC, PubMed, ScienceDirect and Emerald Insight.

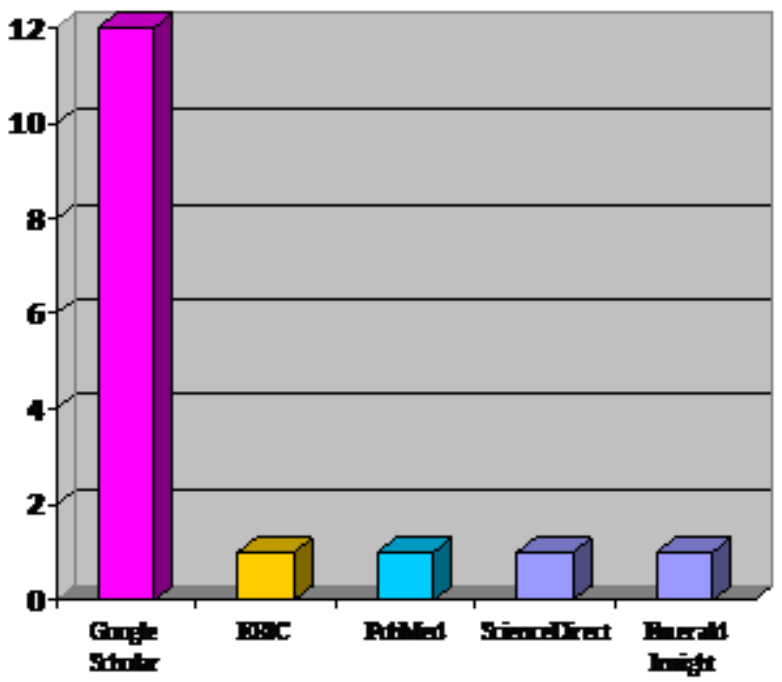

Fig.1. Sources Used

\section{RESULT ANALYSIS}

Researcher found that previous studies are focus on job performance in beauty industry, cosmetology education and training qualification. There are nine studies focused on Korean cosmetology field [19]; [20]; [21]; [22]; [23]; [24]; [25]; [26]; [27]. Other than that, each study examined Pakistan cosmetology field [12], Midwest cosmetology field [28], Netherlands cosmetology field [11], Turkey cosmetology field [1], Taiwan cosmetology field [29] and Ghana cosmetology field were also included in this review.

Regarding the year of publication, two articles were published in 2019 [19]; [25], eight articles were published in 2018 [20]; [21]; [22]; [23]; [26]; [11]; [12]; [27] and two studies were published in 2016 [29]; [2]. Other than that, an article was published in 2014 [24] and 2012 [1].

Past studies have identified that to maintain a successful beauty company and to obtain quality of work environment, emotional intelligence [19], coaching leadership [30] have a good communication [20] needs to be managed efficiently. The study that has been done by [19] involve hair salon workers in Seoul and Gyeonggi-do whereby they conducted their study on emotional intelligence, customer orientation and organizational performance. They found that emotional intelligence had a significant effect on customer orientation and organizational performance.

Apart from that, [19] in their study found other than emotional intelligent, coaching leadership and good communication among all members and clients also show positive significant effect on organizational performance. To have a quality organizational performance in beauty industry, [21] revealed that self-esteem improvement training, stress management and active corresponding measures are necessary to nurture among the cosmetology students before they start to work in the beauty industry.

Other than [20], [22]; [23] in their studies also affirm that communication has a significant effect on organizational trust and it is the important factor for corporate performance. They conduct a quantitative study in Korea which involved employees in Seoul and Gyeonggi.

On another note, 502 4-year students majoring in cosmetology at college in Seoul, Gyeonggi-do, Jeollabuk-do and Chungcheongnamdo needs of the cosmetology curriculums and more classes to improve their cosmetology skills and learn theories [24]. Studies also found that the school systems of the research participants' colleges were not concerned with the cosmetology-related majors and the curriculums. Whereas, cosmetology careers influence refers to individual's self-knowledge and skills to sustain in their profession [28]. In addition, [26] also affirm that practical training was very helpful in student's prior preparation for work for them to gain knowledge and firm their skills.

[12] conducted a study on ethical dilemmas encountered in clinical practice. There are twelve dermatologists in Pakistan have been interviewed by them. They found that ethics education should be implemented through structured programmed to reduce carelessness and ethical issues among dermatologists when handling the clients. [11] also admit that cosmetologists and cosmetology students have to go for training and earn qualification certificate before start working in beauty industry to take care of safety and quality standards both technical and ethical in this field. Other than that, training also important for cosmetology students to upskill their communication skills [1]. [2] also insist that precious knowledge usually gaining from training and only individuals that work hard and have good attitude will get the tacit knowledge from the master.

\section{DISCUSSION}

Various study revealed that in order to compete in the rapidly changing cosmetology industry, it is very important for cosmetologists and cosmetology students to be knowledgeable [28]; [3] and skillful not only on hard skills but also soft skills [31]. [11] and [3] insist that whoever dabble in this field have to go thorough training and qualification before giving treatments to clients. [19] and [23] in their studies also revealed that cosmetologists need educational support, coaching leadership [20], stress management and self-esteem improvement training [21] not only to be knowledgeable and skillful but also learn how to manage their emotional intelligence efficiently, to maintain job performance and also to have good communications [22]. It is also actually important for managers to scale down the number of turnovers among cosmetologists [21].

The reason is once the students enter the working environment, they have to make sure the satisfaction of their clients regarding the treatments given and the consultation given [3]. 
Cosmetologist will be working with people, listening and talking to the clients, learning about the clients and also building relationships with clients [5]. [24] also found that students in Korea need systematic curriculum and extra classes to master up their knowledge and skills on cosmetology field.

[26] also revealed that it is important to have practical training for the cosmetology students as it is useful for their local experiences and preparation for their career. A study by [32] also found that medical students who are expose to workshop and training can build up their improved their knowledge and skills. Other than that, [25] also studied on beauty preferences on teachers when they are teaching cosmetology students. He found that students are more interest to learn when teachers have attractive appearances. In order to be knowledgeable and skillful, cosmetologists have to maintain good relationships with the master because they are willing to share knowledge only with whom they have a pleasant relationship [2].

Table- I: The matrix literature review of result analysis

\begin{tabular}{|c|c|c|c|c|c|c|c|}
\hline Author & Country & Sample & $\begin{array}{c}\text { Size } \\
\text { Sample }\end{array}$ & Design & $\begin{array}{c}\text { Data Collection } \\
\text { Method }\end{array}$ & $\begin{array}{c}\text { Analysis } \\
\text { Techniques }\end{array}$ & Key Findings / Result \\
\hline $\begin{array}{l}\text { Yeo \& } \\
\text { Park } \\
(2019)\end{array}$ & Korea & $\begin{array}{l}\text { Hair salon } \\
\text { workers in Seoul } \\
\text { and Gyeonggi-do }\end{array}$ & 239 & QS & $\mathrm{Q}$ & CFA, SEM & $\begin{array}{l}\text { Cosmetologists need systemic and educational } \\
\text { support to deal with their full emotional range. }\end{array}$ \\
\hline $\begin{array}{l}\text { Yeo \& } \\
\text { Park } \\
(2018)\end{array}$ & Korea & $\begin{array}{l}\text { Hair salon } \\
\text { workers in Seoul } \\
\text { and Gyeonggi-do }\end{array}$ & 378 & QS & $\mathrm{Q}$ & CFA, SEM & $\begin{array}{l}\text { problem-solving ability and job performance are } \\
\text { depending on coaching leadership and good } \\
\text { communication among all members. }\end{array}$ \\
\hline $\begin{array}{l}\text { Seo \& } \\
\text { Park } \\
(2018)\end{array}$ & Korea & $\begin{array}{l}\text { Skin care salons in } \\
\text { Seoul and } \\
\text { Gyeonggi-do }\end{array}$ & 387 & QS & Q & EFA, SEM & $\begin{array}{l}\text { Systematic education (self-esteem improvement } \\
\text { training, stress management and active } \\
\text { corresponding measures) are necessary. }\end{array}$ \\
\hline $\begin{array}{l}\text { Jin \& } \\
\text { Park } \\
(2018)\end{array}$ & Korea & $\begin{array}{l}\text { Make-up } \\
\text { employees in } \\
\text { Seoul and } \\
\text { Gyeonggi }\end{array}$ & 262 & QS & $\mathrm{Q}$ & & $\begin{array}{l}\text { Communication has a significant effect on } \\
\text { organizational trust and innovation behavior and } \\
\text { these are important factors for corporate } \\
\text { performance. }\end{array}$ \\
\hline $\begin{array}{l}\text { Kim \& } \\
\text { Lee } \\
(2018)\end{array}$ & Korea & $\begin{array}{l}\text { Employees } \\
\text { working in Seoul } \\
\text { and Gyeonggi } \\
\text { beauty industry }\end{array}$ & & QS & Q & $\begin{array}{l}\text { Correlation, } \\
\text { simple } \\
\text { regression, } \\
\text { bootstrappi } \\
\text { ng test }\end{array}$ & $\begin{array}{l}\text { Management support education and training, the } \\
\text { compensation system and internal } \\
\text { communication were found to be the internal } \\
\text { marketing factors affecting job satisfaction. }\end{array}$ \\
\hline $\begin{array}{l}\text { Howard } \\
\text { et al. } \\
(2010)\end{array}$ & Midwest & $\begin{array}{l}11^{\text {th }}-12^{\text {th }} \text { grade } \\
\text { students }\end{array}$ & 9 & QLI & $\begin{array}{l}\text { Semi structured } \\
\text { IV }\end{array}$ & & $\begin{array}{l}\text { Job/career influences refers self-knowledge, } \\
\text { support, role models, helping others and } \\
\text { financial benefits. }\end{array}$ \\
\hline $\begin{array}{l}\text { Kim \& } \\
\text { Song } \\
(2014)\end{array}$ & Korea & $\begin{array}{l}\text { Majoring in } \\
\text { cosmetology 4y } \\
\text { students at college } \\
\text { in Seoul, } \\
\text { Gyeonggi-do, } \\
\text { Jeollabuk-do and } \\
\text { Chungcheongnam } \\
\text { do }\end{array}$ & 502 & QS & $\mathrm{Q}$ & $\begin{array}{l}\text { Crossover } \\
\text { analysis } \\
\text { ( } x^{2} \text {-test), } \\
\text { t-test, } \\
\text { One-Way } \\
\text { ANOVA } \\
\text { (Duncan-te } \\
\text { st) } \\
\end{array}$ & $\begin{array}{l}\text { Needs of the cosmetology curriculums and more } \\
\text { classes to improve skills and learn theories and } \\
\text { the school systems of the research participants' } \\
\text { colleges were not concerned with the } \\
\text { cosmetology-related majors and the curriculums. }\end{array}$ \\
\hline $\begin{array}{l}\text { Choi } \\
(2019)\end{array}$ & Korea & $\begin{array}{l}\text { Beauty high } \\
\text { schools, colleges } \\
\text { and universities in } \\
\text { Seoul }\end{array}$ & 216 & QS & $\mathrm{Q}$ & $\mathrm{t}$-test & $\begin{array}{l}\text { Differences were identified in preference and } \\
\text { capability assessment of beauty teachers not only } \\
\text { on the basis of types of make-up and clothing but } \\
\text { also gender and their school type. }\end{array}$ \\
\hline $\begin{array}{l}\text { Kim } \\
(2018 b)\end{array}$ & Korea & 32 unversities & 496 & QS & Q & $\begin{array}{l}\text { multiple } \\
\text { regression }\end{array}$ & $\begin{array}{l}\text { Practical training was helpful in their prior } \\
\text { preparation for work, university and trainee } \\
\text { aspect. }\end{array}$ \\
\hline $\begin{array}{l}\text { Bunnik } \\
\text { et al. } \\
\text { (2018) }\end{array}$ & $\begin{array}{l}\text { Netherlan } \\
\text { ds }\end{array}$ & $\begin{array}{l}\text { ANBOS, } \\
\text { aestheticians }\end{array}$ & 8,7000 & $\begin{array}{l}\text { QS, QLI, } \\
\text { Diss, } \\
\text { Rep, IV }\end{array}$ & & & $\begin{array}{l}\text { Aestheticians are better trained for the } \\
\text { improvement of safety and quality standards } \\
\text { both technical and ethical in their field. }\end{array}$ \\
\hline $\begin{array}{l}\text { Tahir et } \\
\text { al. } \\
\text { (2018) }\end{array}$ & Pakistan & $\begin{array}{l}\text { Dermatologists } \\
\text { working in tertiary } \\
\text { care hospitals } \\
\text { across Pakistan }\end{array}$ & 12 & QLI & $\begin{array}{l}\text { Open ended } \\
\text { semi -structured } \\
\text { in depth IV }\end{array}$ & $\begin{array}{l}\text { Thematic } \\
\text { interactiona } \\
\text { l analysis }\end{array}$ & $\begin{array}{l}\text { Ethical dilemmas in dermatology are } \\
\text { encountered in clinical practice. Peer discussion, } \\
\text { reflections and protocols should be role modeled. } \\
\text { Ethics education should be implemented through } \\
\text { structured programmed as per guidelines of } \\
\text { National Bioethics Committee. }\end{array}$ \\
\hline $\begin{array}{l}\text { Ondogan } \\
\text { \& Benli } \\
(2012)\end{array}$ & Turkey & & & & & & $\begin{array}{l}\text { Education of aestheticians and beauty service } \\
\text { providers involve a large variety of subjects from } \\
\text { aesthetics to health and from cosmetics to care. } \\
\text { As well as high-quality education, improving } \\
\text { personal and communicational skills is also } \\
\text { essential. }\end{array}$ \\
\hline $\begin{array}{l}\text { Park } \\
(2018)\end{array}$ & Korea & & 239 & $\begin{array}{l}\text { QS, } \\
\text { Diss }\end{array}$ & & $\begin{array}{l}\text { Descriptive } \\
\text {, SEM }\end{array}$ & $\begin{array}{l}\text { Efforts should be made to encourage charisma, } \\
\text { individualized consideration, and intellectual } \\
\text { stimulation to increase employee satisfaction. }\end{array}$ \\
\hline $\begin{array}{l}\text { Yan } \\
(2016)\end{array}$ & Taiwan & $\begin{array}{l}20 \text { years and older } \\
\text { with cosmetology } \\
\text { experiences }\end{array}$ & 774 & QLI & $\begin{array}{l}\text { comp-assisted } \\
\text { tel }\end{array}$ & & $\begin{array}{l}\text { Cosmetology industry needs to provide } \\
\text { differentiated services and products to sustain } \\
\text { customer loyalty. }\end{array}$ \\
\hline
\end{tabular}




\begin{tabular}{llccccc}
\hline Author & Country & Sample & $\begin{array}{c}\text { Size } \\
\text { Sample }\end{array}$ & Design & $\begin{array}{c}\text { Data Collection } \\
\text { Method }\end{array}$ & $\begin{array}{c}\text { Analysis } \\
\text { Techniques }\end{array}$ \\
\hline $\begin{array}{l}\text { Agyema } \\
\text { ng \& }\end{array}$ & Ghana & Master hairdresser & 47 & CS, QLI & semi -structured & thematic \\
Boateng & & & & IV & Focuses on the holder of tacit knowledge (master \\
technique & $\begin{array}{l}\text { hairdressers) and reveals their motivations to } \\
\text { transfer or hoard their tacit knowledge. }\end{array}$
\end{tabular}

(2016)

\begin{tabular}{|c|c|c|c|c|}
\hline \multicolumn{5}{|c|}{ QLI: Qualitative Interview } \\
\hline Diss: Discussions & Rep: Report & IV: Interview & $\mathrm{T}$ : Thesis & comp: Computer \\
\hline CFA: Confirmatory facto & nalysis & tel: telephone & CS: case study & \\
\hline EFA: Exploratory factor & alysis & SEM: Structural equation & elling & \\
\hline
\end{tabular}

\section{CONCLUSION}

The necessary effort must be exerted in order to improve the quality of cosmetologists and beauty services education. Therefore, to meet the need for qualified labor force in this sector, proper training, specializing and providing honest services are the crucial elements. This study suggests that an educational intervention on effective learning and teaching strategies have to be conducted. Other than that, cosmetology programmed also have to be developed as stand-alone programmed in public universities in Malaysia due to demands on this cosmetology field. This is part of research study so that, future studies will be discussed on soft skills in cosmetology field.

\section{ACKNOWLEDGMENT}

This work is supported by Universiti Tun Hussein Onn Malaysia under RMC Research Fund Vot E15501.

\section{REFERENCES}

1. E. C. Ondogan and S. Benli, "Aesthetician education and it's significance for the sector," Procedia - Social and Behavioral Sciences, vol. 46, 2012, pp. $4651-4655$.

2. F. G. Agyemang and H. Boateng, "Tacit knowledge transfer from a master to an apprentice among hairdressers," Education and Training, vol. 61(1), 2016, pp. 108-120.

3. Fitzsimmons, S., "Careers in Hairdressing and Beauty Therapy," $7^{\text {th }}$ edition. London: Kogan Paged Limited, 1996. ISBN: 0-7494-1746-3.

4. J. Gerson et al., "Milady's Standard Fundamentals for Estheticians," New York: Dermar Learning, 2004.

5. S. Ganchy, “A Career as a Cosmetologist, ” $1^{\text {st }}$ edition. New York: The Rosen Publishing Group, Inc., 2013. ISBN: 978-1-4488-8240-3.

6. W. Abramovits, "Definition of cosmetology, cosmetics, and other pertinent terms," Clinics in Dermatology, vol. 6(3), pp. 1-8, 1988.

7. J. Y. Park and M. S. Lee, "Influence of beauty care on well-being-oriented behaviors and well-aging behaviors in adult men," Asian Journal of Beauty and Cosmetology, vol. 17(1), pp. 93-106, 2019.

8. H. F. Cheong and S. Kaur, "Mirror, mirror on the wall, who's the fairest 'hunk' of them all? Negotiating a masculine notion of skin whitening for Malaysian men," Journal of Media and Communication Research, vol. 11(1); pp. 54-73, 2019.

9. E. Ritchie, "The relative importance of communication competence, communication satisfaction and commercial friendship in hair stylist-client consultation communication: a coorientational approach," Master's Thesis, University of Wisconsin, 2016.

10. P. I. Khan and A. Tabassum, "Service quality and customer satisfaction of the beauty-care service industry in Dhaka: a study on high-end women's parlors," The Journal of Business in Developing Nations, vol. 12(11), pp. 32-58, 2010.

11. E. M. Bunnik, F. Meulenberg and I. D. Beaufort, "Ethical issues in the beauty salon: the development of national ethics guidelines for aestheticians in the Netherlands," Narrative Inquiry in Bioethics, vol. 8(3); pp. 247-260, 2018.

12. M. Tahir, R. Yasmeen and R. A. Khan, "Exploring practices of dermatologists in ethical dilemmas in Pakistan: a narrative analysis," Pakistan Journal Med Science, vol. 34(2), pp. 374-379, 2018. DOI: https://doi.org/10.12669/pjms.342.14328.

13. J. P. Braxton, "Vocational education in cosmetology," The Clearing House: A Journal of Educational Strategies, Issues and Ideas, vol. 75(1), pp. 4-5, 2001. DOI:10.1080/00098650109599223.

14. H. H. Jung and M. S. Chang, "The reality of cosmetology education \& employment based on vocational competency development account system for career-discontinued women, “Journal Invest. Cosmetology, vol. 11(1), pp. 47-63, 2015.

15. S. H. Jeong, "Purchasing behavior for skin care products by distribution channel," Asian Journal Beauty Cosmetology, vol. 16(4), pp. 545-554, 2018

16. K. J. Kim and H. S. Hun, "Marketing strategies and consumer recognition of medical cosmetics," Asian Journal Beauty Cosmetology, vol. 16(4), pp. 569-578, 2018.

17. K. Danielson, "The future of online cosmetology education in Arizona: a delphi study," Doctoral Dissertation, Degree Doctor of Education in Educational Leadership, University of Phoenix, 2009. DOI: 10.13140/RG.2.2.16162.12485.

18. H. I. Patel, C. Patel and A. Trivedi, "Assessment of affecting factors for higher education admission process," International Journal of Engineering and Advanced Technology (IJEAT), vol. 9(1), pp. 63-67, 2019.

19. Y. J. Yeo and E. J. Park, "Emotional intelligence, customer orientation, and the organizational performance of hair salon workers," Asian Journal of Beauty and Cosmetology, vol. 17(2), pp. 199-209, 2019.

20. Y. J. Yeo and E. J. Park, "The impact of coaching leadership of hair salon managers on problem solving ability and job performance," Asian Journal of Beauty and Cosmetology, vol. 16(3), pp. 393-404, 2018.

21. S. S. Seo and C. H. Park, "Effects of emotional labor for aestheticians on job stress, satisfaction, and turnover. Asian Journal Beauty Cosmetology, vol. 16(3), pp. 333-345 2018.

22. D. H. Jin and E. J. Park, "Communication, organizational trust and innovative behavior of makeup employees in the 20-30s, "Asian Journal Beauty Cosmetology, vol. 16(3), pp. 359-368, 2018.

23. T. Y. Kim and S. N. Lee, "The mediating effect of job satisfaction on the relationship between internal marketing and the customer orientation of employees in the beauty service industry," Asian Journal Beauty Cosmetology, vol. 16(4), pp. 555-567, 2018.

24. G. R. Kim and J. Song, "A Study on the Curriculum Satisfaction and Expected by Beauty-related Majors," Korean Journal Aesthetics Cosmetology, vol. 12(1), pp. 93-103, 2014.

25. S, Choi, "Preference and capability assessment of beauty teachers by the types of make-up and clothing," Asian Journal of Beauty and Cosmetology, vol. 17(2), pp. 257-265, 2019.

26. M. J. Kim, "Affecting and satisfaction factors for practical training of skin care related college students," Asian Journal of Beauty and Cosmetology, vol. 16(2), pp. 221-232, 2018b.

27. S. J. Park, "Mediating effects of organizational commitment on the relationship between beauty industry managers' leadership and customer orientation," Asian Journal of Beauty and Cosmetology, vol. 16(2), pp. 255-265, 2018.

28. K. A. S. Howard, S. L. Budge, B. Gutierrez, A. D. Owen, N. Jones, et al., "Future plans of urban youth: influences, perceived barriers, and coping strategies," Journal of Career Development, vol. 37(4), pp. 655-676, 2010.

29. Y. H. Yan, "The correlation between relationship quality and behavioral intentions exhibited by various cosmetology groups," Health Systems and Policy Research, vol. 3(4), pp. 1-6, 2016. ISSN 2254-9137.

30. T. A. Darojat, A. Rahmat and L. Djaafar, "The effect of work discipline, work motivation and leadership on employee performance at PT Devrindo Widya Karawang - Indonesia," International Journal of Engineering and Advanced Technology, vol. 9(1), 627-630, 2019.

31. R. Stevenson, D. McConnon, S. Mackey and L. Tonkin, "Skill Standards for Cosmetologists," Seattle Central Community College: Broadway Seattle, 1998. Retrieved from https://www.sbctc.edu/colleges-staff/programs-services/workforce-ed ucation/skill-standards-cosmetology.aspx 
32. D. Kumar, U. S. Singh and R. Solanki, “Assessment of a group activity based educational method to teach research methodology to undergraduate medical students of a rural medical college in Gujarat, India," Journal of Clinical and Diagnostic Research, vol. 9(7), pp. 1-3, 2015.

\section{AUTHORS PROFILE}

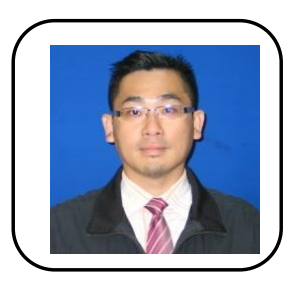

Tee Tze Kiong was born in Melaka, Malaysia on the $25^{\text {th }}$ of April 1979. He obtained his first degree in Bachelor of Technology with Education (Civil Engineering) at Faculty of Education, Universiti Teknologi Malaysia (UTM), Skudai, Johor, Malaysia in 2002. In 2003, he completed his Master's degree in Technical and Vocational Education at UTM, Skudai, Johor, Malaysia. At the year 2013, he obtained his Ph.D. in Technical and Vocational Education, Universiti Tun Hussein Onn Malaysia (UTHM), Batu Pahat, Johor, Malaysia. His Ph.D. research focuses on higher order thinking skills and Buzan Mind Mapping. His working experiences include; secondary school teacher, subject matter expert, e-tutor, e-grader, proctor for final examination at Open University Malaysia, industrial practicum supervisor, undergraduate project, master and Ph.D. thesis supervisor, undergraduate, master and Ph.D. examiner, subject matter expert and examiner in Technical and Vocational Education courses, professional consultant for Multiple Intelligent Tests and Learning Styles Inventory, instrument construction workshop, lecturer and Head of Department of Engineering Technology at Universiti Pendidikan Sultan Idris. Now, he is a senior lecturer in the Department of Professional Education, Faculty of Technical and Vocational Education, at UTHM. Current and previous research interests are thinking skills, thinking tools, self-instructional modular approach, learning styles and inventive problem-solving skills. He is a member of UTM Alumni, UTHM Alumni, Malaysia Technical and Vocational Education Association and TRIZ level I instructor.

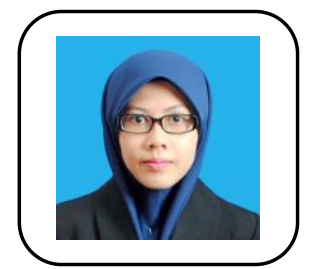

Farah Najwa Ahmad Puad was born in Kedah, Malaysia on the $26^{\text {th }}$ of January 1993. She obtained her first degree in Bachelor of Education (Home Economics) with Honors at Faculty of Technical and Vocational Education, Universiti Pendidikan Sultan Idris (UPSI), Tanjung Malim, Perak in 2016. In 2018, she completed her Master's degree in Master Science of Technical and Vocational Education from UPSI. Currently, she pursues her Doctor of Philosophy $(\mathrm{PhD})$ in Technical and Vocational Education at Faculty of Technical and Vocational Education, UTHM. Her research is focuses on home economics, cosmetology education, modular approach and clothing disposal behavior.

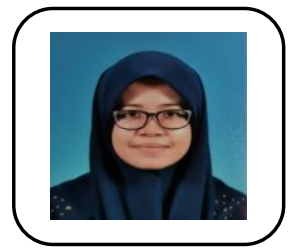

Elia Md Zain was born in Terengganu, Malaysia on the 21th of April 1991. She obtained first degree in Bachelor of Art and Design (Fashion Design) with Honours at Faculty of Art and Design, Universiti Teknologi Mara, Shah Alam, Selangor in 2012. In 2018, she completed her master's degree in Design Technology at Universiti Teknologi Mara, Shah Alam, Selangor. Currently, she pursues her Doctor of Philosophy Ph.D. in technical vocational education at Faculty of Technical and Vocational Education, UTHM. Her research is focuses on fashion, design, active wear, patternmaking and modular approach.

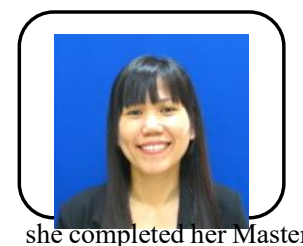

Yee Mei Heong is a senior lecturer at Department of Engineering Education, Faculty of Technical and Vocational Education, UTHM, Batu Pahat, Johor. She obtained her first degree in Bachelor of Technology with Education (Civil Engineering), UTM, Skudai, Johor, Malaysia in 2002. In 2004, 's degree in Technical and Vocational Education at UTM, Skudai, Johor, Malaysia. At the year 2015, she obtained her Ph.D. in Technical and Vocational Education at UTHM. Her research interests on higher order thinking skills, lifelong learning, teaching and learning, learning styles and thinking styles. She is a member of UTM Alumni, UTHM Alumni, Malaysia Board of Technologists (MBOT) and Malaysia Design Council.

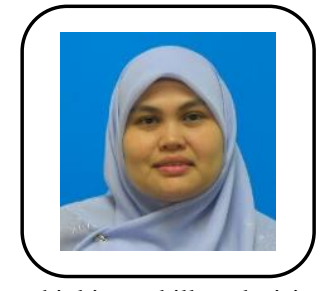

Nurulwahida Azid @ Aziz is senior lecturer at the Universiti Utara Malaysia. Seven years ago, she was teaching at MARA Junior Sciences College. Now she is the Head of Curriculum and Instruction Unit. Nurul's researches mainly focus on the effectiveness of interactive application, enrichment module and interactive module using psychology elements (multiple intelligence, thinking intelligence, higher order thinking skills, decision making skill and problem solving) across curriculum and instruction. Her latest research is about higher order thinking skills in School Based Assessment and the development of interactive application (smart i-think) for teaching and learning science in secondary schools. She has received several awards for her research output from International exhibitions. Among them are Silver and Bronze awards for Malaysian Multiple Intelligence Finder, Gold and Silver for Hisbah Refleksi Al-Nafs. In addition, she has also obtained copyrights for the two research outputs from two national research grants. The latest achievement is 'Special Award for innovation in teaching and learning' awarded by Universiti Utara Malaysia. She has successfully completed 11 research grants since 2011 and now is working on three ongoing research grants. She is at present involved in publication and research using pre-experimental research design, true experimental research design and quasi experimental research design. Currently, she is also a member of the Language Editorial Board for a Scopus journal, International Journal of Instruction, Turkey. 